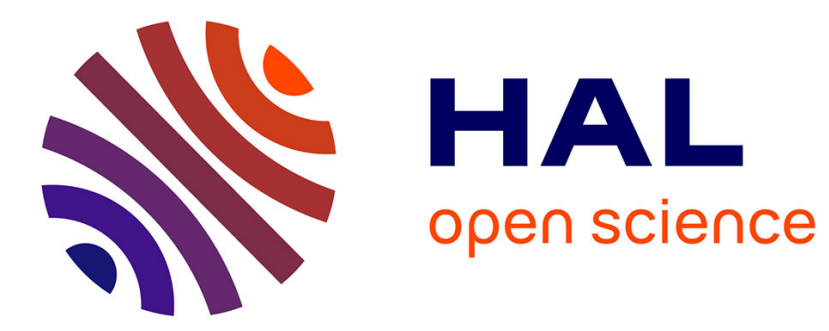

\title{
Comparison of temperature and humidity during MIS 11 and MIS 5e interglacials with the Holocene using stable isotopes in tufa deposits from northern France
}

Julie Dabkowski, Nicole Limondin-Lozouet

\section{- To cite this version:}

Julie Dabkowski, Nicole Limondin-Lozouet. Comparison of temperature and humidity during MIS 11 and MIS 5e interglacials with the Holocene using stable isotopes in tufa deposits from northern France. Quaternary Research, 2022, 107, pp.147-158. 10.1017/qua.2021.66 . hal-03501287

\section{HAL Id: hal-03501287 \\ https://hal.science/hal-03501287}

Submitted on 7 Jan 2022

HAL is a multi-disciplinary open access archive for the deposit and dissemination of scientific research documents, whether they are published or not. The documents may come from teaching and research institutions in France or abroad, or from public or private research centers.
L'archive ouverte pluridisciplinaire HAL, est destinée au dépôt et à la diffusion de documents scientifiques de niveau recherche, publiés ou non, émanant des établissements d'enseignement et de recherche français ou étrangers, des laboratoires publics ou privés. 


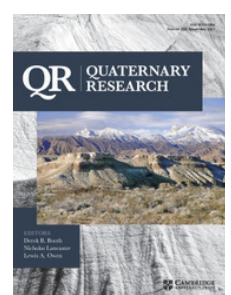

Quaternary Research

Article contents

Abstract

INTRODUCTION

STUDIED AREA AND

SITES

OVERVIEW OF

FORMER ISOTOPIC

DATA FROM THE

PLEISTOCENE SITES

NEW STABLE ISOTOPE

DATA AT SAINT-

GERMAIN-LE-VASSON

INTERSITE

COMPARISONS

DISCUSSION:

INTERGLACIAL

INTENSITIES IN THE

PARIS BASIN

CONCLUSIONS

References
Comparison of temperature and humidity during MIS 11 and MIS 5e interglacials with the Holocene using stable isotopes in tufa deposits from northern France

Published online by Cambridge University Press: 22 December 2021

Julie Dabkowski and Nicole Limondin-Lozouet

Article Figures Metrics

\section{Abstract}

Many recent palaeoclimatic studies have focused on Pleistocene interglacials, especially Marine Isotopic Stages (MIS) 5e and 11, as analogs to our modern interglacial (MIS 1). In continental area, archives allowing comparison between interglacials remain scarce. Calcareous tufa deposits, as they are characteristic of these periods and can provide long, almost continuous, palaeoclimatic records through their isotopic content, appear highly suitable for such investigation. In this paper, $\delta^{18} \mathrm{O}$ and $\delta^{13} \mathrm{C}$ values from the three welldated tufas of Saint-Germain-le-Vasson, Caours, and La Celle are combined to compare temperature and moisture conditions prevailing during MIS 1, 5e, and 11, in the Paris Basin. Both Pleistocene interglacials, and especially their optima, appear stronger than the Holocene: MIS 11 was wetter and warmer than both the Holocene and MIS 5e, which itself experienced wetter conditions than the Holocene. These observations are consistent with palaeontological data from the studied sites, especially malacological assemblages, which record, as at other European tufa sites, a relative depletion of molluscan diversity during the Holocene compared with the Pleistocene (MIS 5 and 11) interglacials.

\section{Keywords \\ Interglacials MIS 5 MIS 11 Holocene Western Europe Temperature Humidity \\ Palaeoclimate Tufa geochemistry Molluscan diversity}

\begin{tabular}{|ll|l|}
\hline Type & Research Article & \\
\hline Information & Quaternary Research, First View, pp. 1 - 12 & Check for updates \\
& DOI: https://doi.org/10.1017/qua.2021.66 & Copyright $\odot$ University of Washington. Published by Cambridge University Press, \\
\hline Copyright & 2021
\end{tabular}

\section{INTRODUCTION}

Many recent palaeoclimatic studies have focused on Marine Isotopic Stages (MIS) $5 \mathrm{e}$ and 11 , as they have long been considered, for different reasons, to be the best analog to our modern interglacial (Tzedakis et al., 2009; Shakun et al., 2015; Past Interglacials Working Group of PAGES, 2016). For interglacial comparisons, most investigations have focused on long marine or ice core records; fewer archives covering almost continuously interglacial periods are available for continental areas (Lang and Wolff, 2011; Past Interglacials Working Group of PAGES, 2016).

Because they are characteristic of wet and temperate periods (Pentecost, 1995, 2005), calcareous tufas are key archives for studying interglacials. These continental open-air deposits result from calcite precipitation from meteoric waters at ambient temperature (Capezzuoli et al., 2014) and are thus suitable targets for palaeoclimatic reconstructions, especially from oxygen and carbon stable isotopes (Andrews, 2006; Dabkowski et al., 2011). Furthermore, they routinely host evidence of past environmental conditions via wellpreserved faunal and floral assemblages that, together with calcite, provide supports for various radiometric dating methods (mainly U/Th series and radiocarbon) (Dabkowski, 2014).

Tufas are particularly favourable both to the development of molluscan communities and the in situ preservation of their shells, allowing an accurate reconstruction of the progressive forest extension during interglacial periods (Preece, 1991). In western Europe, malacological studies undertaken in recent years have already demonstrated a significant decrease in the Holocene forest land snail diversity compared with the Pleistocene (Limondin-Lozouet and Preece, 2014). This difference is due to the occurrence within 
Pleistocene successions of several species with current ranges centred within central and southern Europe, having never reached the westernmost part of Europe during the Holocene.

Using isotopic data from Caours (Somme) and La-Celle-sur-Seine (Seine-et-Marne) respectively assigned to MIS $5 e$ and MIS 11, and previously unpublished data from SaintGermain-le-Vasson tufa (Normandy) dated to the first half of the Holocene, we investigate climatic similarities or differences between these Pleistocene interglacials and the modern one that may have affected species distribution.

\section{STUDIED AREA AND SITES}

\section{General settings}

The three sites included in this study are located in the Paris Basin (Fig. 1), which corresponds with most of the northern half of France and is surrounded by the Armorican massif (west), the Massif Central (south), and Vosges and Ardennes (east and northeast). The Paris Basin comprises mainly post-Triassic carbonate formations (Pomerol, 1974) that extend north to the London Basin in England. This calcareous bedrock provides calcium $\left(\mathrm{Ca}^{2+}\right)$ and bicarbonate $\left(\mathrm{HCO}_{3}{ }^{-}\right)$ions that are dissolved and transported by groundwater to springs and rivers where they can precipitate as tufa calcite $\left(\mathrm{CaCO}_{3}\right)$. The most important aquifer in the Paris Basin is the porous Upper Cretaceous chalk, with numerous secondary and tributary aquifers.

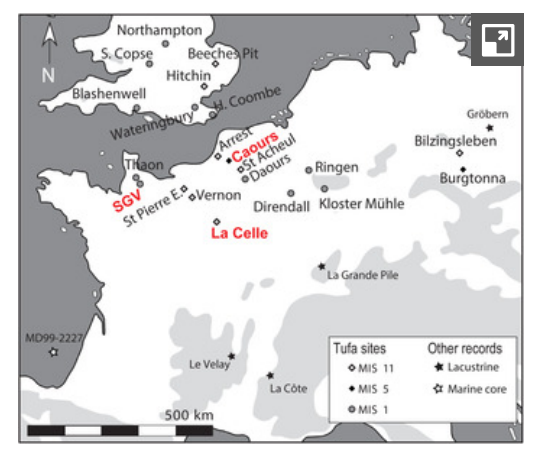

Figure 1. Location map of Saint-Germain-le-Vasson (SGV), Caours, and La Celle (in red) and other tufa sequences and interglacial European records discussed in this paper.

Modern meteorological data are from Météo-France stations near the studied sites (Caen, Abbeville, and Melun stations; Table 1). The average annual temperatures are around $11^{\circ} \mathrm{C}$ at all sites, with seasonal average temperatures around $5^{\circ} \mathrm{C}-6^{\circ} \mathrm{C}$ in winter (January to March) and $17-18^{\circ} \mathrm{C}$ in summer (July to September). Average annual precipitation ranges from $676.8 \mathrm{~mm}$ at Melun (near La Celle) to $782.6 \mathrm{~mm}$ at Abbeville (near Caours). At all sites, precipitation occurs evenly across the year. Saint-Germain-le-Vasson, Caours, and La Celle therefore currently experience similar weather patterns typical of a temperate oceanic climate. Additionally, extrapolations from the Online Isotopes in Precipitation Calculator (Bowen and Revenaugh, 2003; Bowen, 2020) provide very similar mean annual $\delta^{18}$ O values for modern precipitation, around $-7.7 \%$ at each site (Table 2 ). This confirms that modern rainfall at Saint-Germain-le-Vasson, Caours, and La Celle has the same oceanic source and that there is virtually no continental effect (decrease in the oxygen isotopic values due to the rainout effect throughout the continent; Andrews, 2006) observed from the westernmost site, Saint-Germain-le-Vasson, to the easternmost, La Celle.

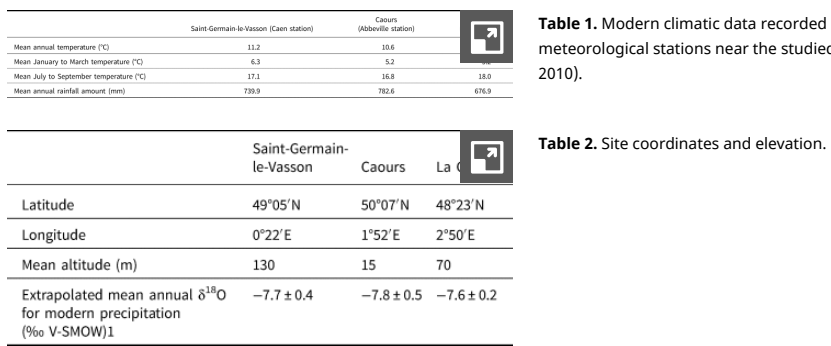

1 Mean annual extrapolated $\delta^{18} \mathrm{O}$ of modern precipitation extrapolated at the site locations using the Online Isotopes in Precipitation Calculator (Bowen, 2020).

Two Pleistocene sites 
The tufa sequence at Caours, near Abbeville in the Somme basin (Fig. 1, Table 2), covers a surface of several thousand square metres at the confluence of the Scardon and Drucat streams, with an average thickness of 3 to $4 \mathrm{~m}$ (Fig. 2). This tufa was mainly formed on the valley slope, fed by perched springs emerging from the Upper Cretaceous chalk, the largest aquifer in the Paris Basin, which provides carbonate to calcite precipitation.

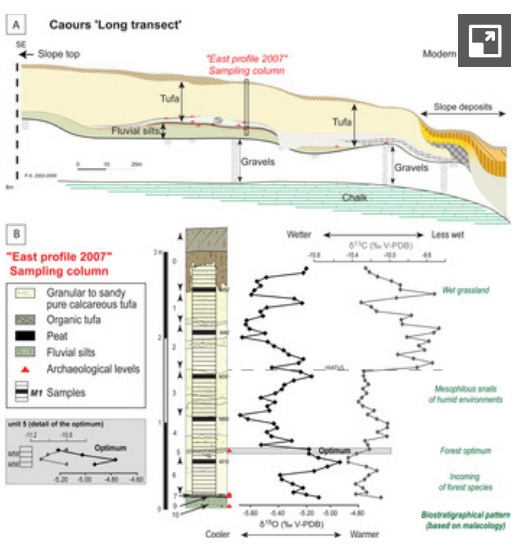

Figure 2. Overview of stratigraphic and isotopic data from previous investigations at Caours: (A) Long transect along the slope made by combining observations from several boreholes, cores, and stratigraphic sections and showing the fluvial terrasse (gravel and silts) underlying the chalk, the tufa deposit, and posterior slope deposits (modified after Antoine et al., 2006), as well as the position of the sampling column. (B) Details of the stratigraphy of the "Est profile 2007" at the sapetiils of the stratigraphy of the "East profile 2007 at the sampling column position and a summary of palaeoclimatic (tufa calcite $\delta{ }^{18} \mathrm{O}$ and
$\delta^{13} \mathrm{C}$ ) and palaeoenvironmental information (modified after $\delta$ C) and palaeoenvirot

Since 2003, interdisciplinary investigations at Caours have resulted in extended stratigraphic descriptions, dating, and palaeoenvironmental reconstructions (Antoine et al., 2006). The discovery of several Middle Palaeolithic levels, associated with abundant faunal remains and lithic artefacts, led to archaeological excavations (Locht et al., 2009, 2017). Caours tufa overlies alluvial deposits of the Etouvie Formation (Fig. 2), which is assigned to MIS 6 (Saalian) in the well-known Somme valley terrace system (Antoine et al., 2007). According to malacological data, the transition between the cold Saalian and the Eemian interglacial (MIS $5 e$ ) is recorded at the base of the sequence in the fluvial silty deposits preceding the tufa (Antoine et al., 2006). The chronostratigraphic attribution of the sequence to the Eemian interglacial was largely confirmed by geochronological data (Useries on calcite, optically stimulated luminescence on quartz grains, and Electron Spin Resonance (ESR)/U-series on tooth), giving an average age of $123 \pm 3$ ka (Antoine et al., 2006; Bahain et al., 2010; Sier et al., 2015). Mammal fauna remains preserved in the archaeological levels allow the reconstruction of environments at the time of human occupations and strengthen the continuous record of the environment evolution at Caours based on the malacological succession (Antoine et al., 2006; Locht et al., 2009). The latter shows a clear forest maximum that has been demonstrated to be contemporaneous with the MIS 5e optimum through comparison with previously published palaeoclimatic reconstructions from stable isotopes on tufa calcite (Dabkowski et al., 2011, 2016; Fig. 2).

\section{La Celle}

La-Celle-sur-Seine (town of Vernou-La-Celle-sur-Seine) is located in the Seine valley, near Moret-sur-Loing (Seine-et-Marne; Fig. 1, Table 2). The tufa developed on the right-hand side of the Seine valley, $2.5 \mathrm{~km}$ upstream from its confluence with the Loing River. It was formed from springs located upslope and accumulated as an 8- to 15-m-thick body covering an area of ca. 12.5 ha. In its lower part, the tufa lies on the fluvial deposits of a middle terrace of the Seine (Fig. 3), about $15 \mathrm{~m}$ above the modern alluvial plain: its upper part directly overlies the Upper Eocene Calcaire de Champigny (Limondin-Lozouet et al., 2010). This calcareous bedrock is part of the multilayered Champigny aquifer, which comprises different Eocene deposits from the Calcaires de Brie to the Lutetian limestone (Paris stone), above the Upper Cretaceous chalk. The Champigny aquifer was the source of the carbonates feeding La Celle tufa precipitation.

Figure 3. Overview of stratigraphic and isotopic data from previous investigations at La Celle: (A) Drawing of the long profile showing sandy to silty fluvial deposits (units 16-14) underlying the Champigny limestone (unit 17), the tufa deposit (units 13-1), and the position of the sampling column. (B) Details of the stratigraphy at the sampling column position and a summary of palaeoclimatic (tufa calcite $\delta^{18} \mathrm{O}$ and $\delta^{13} \mathrm{C}$ ) and palaeoenvironmental information (modified after Limondin-Lozouet et al., 2010; Dabkowski et al., 2012).

New investigations undertaken at La Celle since 2003 combine stratigraphy, palaeontology, dating, and archaeology (Limondin-Lozouet et al., 2006, 2010; Jolly-Saad et al., 2007). The chronological attribution of the tufa to MIS 11 based on its morphological position within the Seine valley terrace system (Lautridou et al., 1999) was reinforced by new palaeontological evidence (occurrence of the malacological "Lyrodiscus assemblage") and several radiometric dates ( $U / T h$ thermal ionization mass spectrometry on calcite and ESR$\mathrm{U} / \mathrm{Th}$ on tooth enamel) suggesting an age around $400 \mathrm{ka}$ (Bahain et al., 2010; Limondin- 
Lozouet et al., 2020). The malacological succession allowed detailed palaeoenvironmental reconstruction showing the progressive development of forest biotopes with a clear maximum correlated to the MIS 11 climatic optimum (Fig. 3), as shown by comparison with palaeoclimatic reconstructions from stable isotopes on tufa calcite (Dabkowski et al., 2011, 2012; Limondin-Lozouet et al., 2020). The identification of temperate conditions is reinforced by the occurrence of leaf and fruit prints of Mediterranean taxa (e.g., Buxus, Ficus; Jolly-Saad et al., 2007) as well as by records of several thermophilous mammal taxa, including Hippopotamus and Macaca (Limondin-Lozouet et al., 2006). The latter were found associated with Acheulean lithic artefacts that demonstrate human occupation of the site during the climatic optimum (Limondin-Lozouet et al., 2010).

\section{A Holocene site: Saint-Germain-le-Vasson}

Saint-Germain-le-Vasson (SGV) is located in Normandy about $15 \mathrm{~km}$ south of Caen (Fig. 1, Table 2). The tufa is developed on a platform, less than $500 \mathrm{~m}$ from the head of a small dry valley, leading to the right bank of the Laize River. At certain times of the year, water flows from a spring in the lower part of this small valley, but the fossil tufa is now dry, located $200 \mathrm{~m}$ east of the present spring and about $10 \mathrm{~m}$ higher. The source of the carbonate was probably the Calcaire de Caen, which crops out about $1 \mathrm{~km}$ southeast of the site (LimondinLozouet and Preece, 2004). This Middle Jurassic formation constitutes a tributary aquifer fed by the Upper Cretaceous chalk aquifer (Pomerol, 1974; Rodet, 2007).

In the early 2000s, new investigations at SGV provided a stratigraphic description of the 9.5m-high tufa deposit and detailed palaeoenvironmental reconstructions (Limondin-Lozouet and Preece, 2004; Limondin-Lozouet et al., 2005). Seven radiocarbon dates (on charcoal, mollusc shells, and wood) provided a coherent chronology that assigns the SGV tufa to the first half of the Holocene, between $9700 \pm 90$ and $4213 \pm 77{ }^{14} \mathrm{C}$ yr BP, while malacological and palynological data confirm the full record of the Atlantic climatic optimum in the sequence (Limondin-Lozouet et al., 2005).

\section{OVERVIEW OF FORMER ISOTOPIC DATA FROM THE PLEISTOCENE SITES}

Caours and La Celle geochemical data have been previously published and extensively discussed as records of intra-interglacial climate variations during MIS 5 e and 11, respectively (Dabkowski et al., 2011, 2012, 2016). This section presents a brief overview of the former stable isotope investigations, including information useful for the following comparison with unpublished Holocene data from SGV (see "New Stable Isotope Data at Saint-Germain-Le-Vasson" and "Discussion"), also shown on Figures 2-4 and in Tables 3 and 4 .

Figure 4. Overview of previous investigation at Saint-Germain-leVasson (SGV) and unpublished geochemical data: (A) Map of the tufa quarry at SGV showing the position of the different

boreholes and stratigraphic sections. (B) Stratigraphic correlations of the profiles studied showing the development of the tufa deposits over nearly $10 \mathrm{~m}$ (modified after Limondin-Lozouet and Preece, 2004). (C) Detail of the highest stratigraphic profile (Borehole 1), position of the geochemical samples, and summaries of palaeoenvironmental (after Limondin-Lozouet et al., 2005) and palaeoclimatic (tufa calcite $\delta^{18} \mathrm{O}$ and $\delta^{13} \mathrm{C}$ ) information.

Both Caours and La Celle sequences were sampled by hand continuously, every $5 \mathrm{~cm}$, with the exception of some coarser layers at La Celle that could not be sampled properly (as units 2 and 9 mainly comprise large reworked tufa blocks; Fig. 3). Sample columns were placed where most of the stratigraphic units are present in order to cover the longest possible time interval (Figs. 2 and 3). A total of 59 and 117 samples were analysed at Caours and La Celle, respectively. Measurement of oxygen and carbon isotopic ratios was performed at the Stable Isotope Laboratory of the University of East Anglia (UK) using the same protocol described later for SGV; replicate analyses of the laboratory standard ( $n=75$ ) gave $2 \sigma$ precision of $\pm 0.09 \%$ for $\delta^{18} \mathrm{O}$ and $\pm 0.3 \%$ for the $\delta^{13} \mathrm{C}$. The stable isotope results for Caours range from -5.21 to $-4.76 \pm 0.09 \%$ for $\delta^{18}$ O (mean value: $-5.35 \pm 0.09 \%$; $\mathrm{n}=59$ ) and from -11.1 to $-10.8 \pm 0.3 \%$ for $\delta^{13} \mathrm{C}$ (mean value: $-10.1 \pm 0.3 \% ; n=59 ;$ Table 3 ). At La Celle, the $\delta^{18} \mathrm{O}$ values range between -5.79 and $-4.32 \pm 0.09 \%$ (mean value: $-5.00 \pm 0.09 \%$ ) and $\delta^{13} \mathrm{C}$ values between -12.1 and $-7.9 \pm 0.3 \%$ (mean value: $-10.1 \pm 0.3 \%$, $\mathrm{n}=116$; Table 3).

The MIS 5e climatic optimum was clearly identified at Caours in stratigraphic unit 5 by a 
maximum diversity of molluscs (including the widest range of forest species; Antoine et al., 2006) contemporaneous with maximal temperature and humidity conditions recorded by geochemical proxies (Dabkowski et al., 2016; Fig. 2). Summaries of $\delta^{18} \mathrm{O}$ and $\delta^{13} \mathrm{C}$ data attributed to this climatic optimum are presented in Table $4(n=4)$. They range respectively from -5.21 to $-4.76 \pm 0.09 \%$ and from -11.1 to $-10.8 \pm 0.3 \%$.

At La Celle, a maximum in diversity and number of forest species, correlated with wetter and warmer conditions, is similarly observed in stratigraphic unit 7 and has been assigned to the MIS 11 climatic optimum (Dabkowski et al., 2012; Limondin-Lozouet et al., 2020; Fig. 3). Summaries of stable isotope data from this optimum are presented in Table $4(n=12)$. $\delta^{18} \mathrm{O}$ values range from -5.01 to $-4.32 \pm 0.09 \%$ and $\delta^{13} \mathrm{C}$ values from -11.2 to $-10.5 \pm 0.3 \%$.

At La Celle, the uppermost unit (unit 1) also stands out from the rest of the sequence, as it records specific, cooler and wetter, climatic conditions associated with molluscan assemblages characterised by more tolerant forest species and grassland molluscs (unit 1 ; Fig. 3). This forest regression observed at the transition between units 1 and 2 (Fig. 3) could correspond either to the final phase of the deciduous forest or to the last development of the boreal humid forest at the very end of the interglacial period (Limondin-Lozouet et al., 2020).

\section{NEW STABLE ISOTOPE DATA AT SAINT-GERMAIN-LE-VASSON}

\section{Methods}

At SGV, the tufa sequence was regularly sampled by hand according to stratigraphy, except for the most indurate units, with maximal thickness of $10 \mathrm{~cm}$ for each sample. Sixty-two samples were analysed for carbon and oxygen stable isotope composition, covering the whole tufa sequence in the most complete profile (Borehole 1), up to $-946 \mathrm{~cm}$ of relative depth from the top (Fig. 4).

As at Caours and La Celle, approximately $1 \mathrm{~g}$ of each field-collected sample was sifted to $250 \mu \mathrm{m}$, and the fine fraction was cleaned of volatile organic matter by low temperature (< $80^{\circ} \mathrm{C}$ ) oxygen plasma etching for $6 \mathrm{~h}$ at $300 \mathrm{~W}$ forward power in a Bio-Rad PT 7300 plasma barrel etcher. Subsamples of $100 \pm 10 \mu \mathrm{g}$ of plasma-ashed tufa were then reacted with anhydrous $\mathrm{H}_{3} \mathrm{PO}_{4}$ at $90^{\circ} \mathrm{C}$, and isotopic ratios of the resulting $\mathrm{CO}_{2}$ were measured on a Europa Sigma Hybrid with an in-house autosampler at the Stable Isotope Laboratory of the University of East Anglia. Sixty-nine replicate analyses of the laboratory standard gave $2 \sigma$ precisions of $\pm 0.2 \%$ for $\delta^{18} \mathrm{O}$ and $\pm 0.5 \%$ for $\delta^{13} \mathrm{C}$.

\section{Results}

Isotopic data from Saint-Germain-le-Vasson range between -5.7 and $-4.9 \pm 0.2 \%$ for $\delta^{18} \mathrm{O}$ (mean value: $-5.3 \pm 0.2 \%$; $\mathrm{n}=62$ ) and between -10.5 and $-7.9 \pm 0.5 \%$ for $\delta^{13} \mathrm{C}$ (mean value: $-9.3 \pm 0.5 \%$; Table 3). Most of the observed variation in both $\delta^{18} \mathrm{O}$ and $\delta^{13} \mathrm{C}$ is small compared with the confidence intervals (Table 3). Consequently, the climatic optimum could not be clearly defined at SGV: molluscs record shaded damp environments characteristic of a dense forest development in a large part of the sequence, and malacological zones are not correlated with any specific events in the stable isotope record that show little or no variation (Fig. 4). A few palynological samples provide assemblages characteristic of the Atlantic, but they are discontinuous (as pollen is only preserved in the most organic layers, which are rare; Limondin-Lozouet et al., 2005; Fig. 4) and do not allow proper delimitation of this period within the sequence, as is the case at Caours and La Celle.

\section{INTERSITE COMPARISONS}

When compared with data from other well-dated Late Quaternary (mainly Holocene) European tufas (Andrews, 2006), SGV results appear consistent with those from Belgium and the United Kingdom (Fig. 5). They are thus typical of temperate latitudes where soil contribution to $\delta^{13} \mathrm{C}$ is predominant, as soils and vegetation are well developed. These observations strengthen the position of SGV as a reference for the Holocene in the Paris Basin. 
continentality and aridity/evaporation effects are low (Andrews, 2006; Fig. 5). This suggests that the three sites were part of similar climatic zones despite their age disparity. This assumption is strengthened by our previous comments on the modern weather patterns and rainfall $\delta^{18} \mathrm{O}$ values at each site (Tables 1 and 2), showing that SGV, Caours, and La Celle are part of the same temperate oceanic climate zone in the present.

\section{Caours/SGV}

Isotopic data from Caours (MIS 5e) and SGV (first half of the Holocene) are plotted together in Figure 6. Two-tailed Student's $t$-tests on unpaired data gave $p$-values lower than the 0.05 limit; Caours and SGV are therefore statistically different regarding both $\delta^{18} \mathrm{O}$ and $\delta^{13} \mathrm{C}$ values, although their respective means are similar according to confidence intervals (Table 3).

In detail, the $\delta^{18} \mathrm{O}$ values from Caours optimum appear slightly higher $(-4.98 \pm 0.09 \%$; Table 4) than those from the entire sequences of Caours and SGV $(-5.35 \pm 0.09 \%$ and $-5.3 \pm 0.2 \%$, respectively; Table 3). However, they range from -5.21 to $-4.76 \pm 0.09 \%$ (Table 4 ), which partly covers the whole sequence and SGV $\delta^{18}$ O variability (Fig. 6, Table 3). About a third of the SGV $\delta{ }^{18}$ O range (37\%, represented by 26 of 62 samples) actually overlaps with Caours optimum $\delta^{18} \mathrm{O}$ data (Fig. 6).

Caours $\delta^{13} \mathrm{C}$ values clearly present a narrow range compared with those from SGV (Fig. 6), as shown by their respective standard deviations ( 0.6 at SGV vs. 0.3 at Caours; Table 3). All carbon isotopic values for Caours are actually lower than the SGV $\delta{ }^{13} \mathrm{C}$ mean value $(-9.3 \pm 0.5 \%)$. Both with respect to their mean value $(-10.9 \pm 0.3 \%)$ and range $(-11.1$ to -10.8; Table 4), Caours optimum $\delta^{13} \mathrm{C}$ values appear lower than those from the rest of the sequence and from SGV (Fig. 6).

\section{La Celle/SGV}

Isotopic data from La Celle (MIS 11) and SGV are plotted together on Figure 7. Two-tailed Student's $t$-tests on unpaired data gave $p$-values below the 0.05 threshold, suggesting that both $\delta{ }^{18} \mathrm{O}$ and $\delta{ }^{13} \mathrm{C}$ values are statistically different between La Celle and SGV. It may be noted that the same tests performed on the Caours and La Celle data also gave a $p$-value lower than 0.05 for $\delta^{18}$ O but $p=0.6$ for $\delta^{13} \mathrm{C}$, suggesting that there is no statistical difference in the carbon isotope variability of the Pleistocene sites.

La Celle and SGV show close $\delta^{18} \mathrm{O}$ mean values with respect to confidence intervals $(-5.00 \pm 0.09 \%$ and $-5.3 \pm 0.2 \%$, respectively; Table 3$)$ but oxygen isotope values from La Celle have a wider range (resulting in a higher standard deviation: $\sigma=0.3$ ), especially toward higher values (up to $-4.32 \pm 0.09 \%$ compared with a $-4.9 \pm 0.2 \%$ maximum at SGV; Fig. 7, Table 3). The climatic optimum at La Celle is recorded by a notably higher mean $\delta^{18} \mathrm{O}$ value than at SGV $(-4.65 \pm 0.09 \%$ and $-5.3 \pm 0.2 \%$, respectively; Tables 3 and 4$)$. Additionally, the $\delta{ }^{18} \mathrm{O}$ values of the La Celle optimum are higher than all SGV values; only 1 of the 12 values assigned to La Celle optimum is actually within the $\delta^{18} \mathrm{O}$ range of SGV (Fig. 7).

Mean carbon isotope values from SGV and La Celle are similar $(-9.9 \pm 0.5 \%$ and $-10.1 \pm 0.3 \%$, respectively; Table 3$)$. However, the $\delta^{13} \mathrm{C}$ values recorded at La Celle are far lower than those from SGV (down to $-12.1 \pm 0.3 \%$ compared with the SGV minimum of $-10.5 \pm 0.5 \%$; Table 3). Most of the lowest $\delta^{13} \mathrm{C}$ values from La Celle are actually recorded in the same stratigraphic unit of the sequence (wet and cooler episode in unit 1; Fig. 3), associated with relatively high $\delta^{18} \mathrm{O}$ values (Fig. 7). The La Celle climatic optimum also exhibits more negative $\delta^{13} \mathrm{C}$ values than the rest of the sequence and SGV, having a lower mean value $(-11.0 \pm 0.3 \%$; Table 4$)$. Additionally, the La Celle range of $\delta^{13} \mathrm{C}$ values $(-11.2$ to $-10.5 \pm 0.3 \%$; Table 4$)$ does not overlap with the SGV range of $\delta^{13} \mathrm{C}$ values $(-10.5$ to $-7.9 \pm 0.5 \%$; Fig. 4, Table 3). When these two specific clusters of data (from the climatic optimum and from unit 1) are excluded, the La Celle $\delta^{13} \mathrm{C}$ values appear similar to those from SGV (Fig. 7).

\section{DISCUSSION: INTERGLACIAL INTENSITIES IN THE PARIS BASIN}

Climatic parameters influencing stable isotopes in modern and Quaternary tufas in Europe have been well identified (Andrews et al., 1997; Andrews, 2006; Dabkowski et al., 2011). Tufa calcite $\delta^{18} \mathrm{O}$ is directly linked to local airmass composition, which depends mainly on its 
source, rainout effects due to continentality or processes such as the amount effect, and changes in the atmospheric temperature (Andrews et al., 1993, 1997). As noted earlier, the three studied sites are part of the same climatic area (i.e., under the influence of the same airmass), and no continental effect is observed in the present-day rainfall $\delta^{18} \mathrm{O}$.

Furthermore, under oceanic climate, precipitation occurs evenly across the year as currently recorded at meteorological stations near the studied sites, while isotopically anomalous rainfall events are unlikely to be recorded in well-mixed groundwater because of long-term homogenisation within most, and especially large, aquifers (Darling, 2004), like the chalk and limestones of the Paris Basin. In addition, the three studied tufas, formed in close proximity to the springs, are unlikely to have been affected by processes such as evaporation. Consequently, the differences in the $\delta^{18} \mathrm{O}$ of studied sites must reflect differences in atmospheric temperature: higher $\delta^{18} \mathrm{O}$ values corresponding to warmer conditions (Andrews, 2006). On the other hand, tufa calcite $\delta^{13} \mathrm{C}$ is influenced by biomass type/abundance and rainfall amount (i.e., moisture availability), which control the relative contribution of two distinct sources of carbonate into the precipitating water. Under wetter conditions, well-developed vegetation and soils provide low $\delta^{13} \mathrm{C}$, while increasing rainfall leads to shorter groundwater residence time within the aquifer and, in turn lower dissolution of the marine carbonate with typical higher $\delta^{13} \mathrm{C}$ : increasing moisture availability thus results in lower $\delta^{13} \mathrm{C}$ (Andrews, 2006).

\section{MIS 5e versus the Holocene}

The comparison of isotopic data from Caours and SGV suggests that MIS $5 \mathrm{e}$ did not experience different temperature conditions than the first half of the Holocene (including the Atlantic optimum), although its optimum would have known slightly warmer conditions (higher $\delta^{18} \mathrm{O}$ values; Fig. 6). On the other hand, the discrepancies observed in carbon isotope data suggest: (1) that MIS 5 e had moisture conditions similar to the wettest conditions recorded during the first half of the Holocene, but with apparently smaller amplitudes of variations; and (2) that the MIS 5 e climatic optimum was wetter than the first half of the Holocene (including the Atlantic optimum). However, parallel analyses of $\mathrm{Mg} / \mathrm{Ca}$ and $\mathrm{Sr} / \mathrm{Ca}$ ratios in calcite, which are mainly influenced in tufa by the amount of precipitation (Garnett et al., 2004), show that increasing moisture conditions at Caours was due more to vegetation/soil development than to strictly climatic (rainfall) variations (Dabkowski et al., 2016).

At Caours, the malacological faunal list is clearly characteristic of an interglacial and includes several forest species originating from central Europe and that are thus beyond their modern range (Limondin-Lozouet and Preece, 2014). However, no specific species or biome suggests that environmental/climatic conditions were significantly warmer or wetter than during the Holocene (Antoine et al., 2006; Limondin-Lozouet, 2011). Large mammal remains preserved in archaeological levels at Caours mainly belong to red deer (Cervus elephus), fallow deer (Dama dama), and aurochs (Bos primigenius). Other large herbivores are also present but occur less frequently (Dicerorhinus hemitoechus, Equus sp., Capreolus capreolus, Sus scrofa), as do Ursus arctos and Aonyx antiqua. These species are characteristic of interglacial conditions during the middle Pleistocene and the beginning of the late Pleistocene (Antoine et al., 2006; Locht et al., 2009). None indicate particularly warm and wet conditions compared with the Holocene. These palaeoenvironmental data are thus consistent with our observations based on stable isotope comparisons.

In northwestern Europe, only a few continental records have provided long-term quantitative climate reconstructions for MIS 5 e. The lacustrine sequence of La Grande Pile in the Vosges (Fig. 1) has been the reference record for the Paris Basin since the 1970s and has supported numerous palaeoenvironmental studies mainly based on pollen, chironomids, and Coleoptera (Woillard, 1978; de Beaulieu, 1992; Ponel, 1995; Cheddadi et al., 1998). Coleoptera assemblages, and especially quantitative reconstructions of seasonal temperatures by the mutual climatic range method, suggest that the MIS 5e optimum at La Grande Pile was slightly warmer than today and possibly wetter (Ponel, 1995; Ponel et al., 2003). More recently, reconstructions of annual and seasonal temperatures and precipitation combining pollen and organic matter $\delta^{13} \mathrm{C}$ data have been obtained from a new core covering part of MIS 5 (130-100 ka), including MIS 5e (Rousseau et al., 2006, 2007). Despite two short cool events that might not be recorded at Caours due to sedimentary hiatuses (Dabkowski et al., 2016), mean annual climatic conditions similar to those of the present day are recorded at La Grande Pile during the Eemian. However, the climatic optimum at La Grande Pile appears slightly warmer and is characterised by a significant increase in mean annual precipitation. These data are consistent with the similar temperature and moisture conditions recorded during MIS 5 e at Caours compared with SGV data. In addition, the mean annual precipitation signal shows no particular trend or 
variation after the climatic optimum at La Grande Pile, which appears consistent with apparently stable conditions reflected by the low variability of the $\delta^{13} \mathrm{C}$ at Caours during MIS 5e (Fig. 2) compared with the Holocene (SGV; Fig. 4).

Farther east, at Gröbern in central Germany (Fig. 1), seasonal temperatures and mean annual precipitation during the Eemian were reconstructed using a multivariate probabilistic method on pollen and plant microfossil assemblages and indicate warmer conditions (especially during summer) than today and a relatively low level of mean annual precipitation (Kühl et al., 2007). However, this site is located in an area presently characterised by a strong continental climate, which may explain the discrepancies with our data from the Paris Basin. Different regional climatic responses to global variations during MIS $5 e$ have indeed been suggested by the comparison of several terrestrial pollen sequences across western Europe (Sánchez Goñi et al., 2005).

Regional quantitative climate reconstructions are also provided from a Bay of Biscay core (MD99-2227; Fig. 1) applying the modern analog technique to high-resolution pollen data: they indicate that the warmest period of the Eemian was significantly warmer than the present day in terms of temperatures of the warmest month (Sanchez Goni et al., 2012). These higher temperatures are contemporaneous with fast development of forest cover in Europe during the Eemian; the increase in temperate forest pollen percentages is twice as large and rapid at the onset of the Eemian compared with the Holocene. Such rapid development of forest environments would have significantly increased the contribution of soil and vegetation to tufa $\delta^{13} \mathrm{C}$ at Caours and may explain the low values recorded during the optimum compared with the rest of the sequence and with Holocene data from SGV (Fig. 6).

\section{MIS 11 versus the Holocene}

Comparison of $\delta^{18} \mathrm{O}$ variability of La Celle and SGV (Fig. 7) suggests that temperatures were similar to warmer during MIS 11 than during the first half of the Holocene. However, climatic conditions during the MIS 11 climatic optimum appear notably warmer compared with those during the first half of the Holocene (including the Atlantic optimum).

Regarding moisture availability, carbon isotopic data show that MIS 11 was mostly comparable to the first half of the Holocene, except during the climatic optimum and during the last phase recorded at La Celle (unit 1; Fig. 3), which both appear to have been wetter. The latter is also characterised by relatively cooler conditions (Fig. 7).

The strong consistency between the stable isotope variations and the malacological succession of La Celle has already been demonstrated in previous publications (Dabkowski et al., 2011, 2012). The La Celle molluscan record is characterised by the recognition of the "Lyrodiscus fauna," which mainly comprises forest species, including taxa currently having central and southern European ranges (Rousseau et al., 1992; Rousseau, 2003; LimondinLozouet et al., 2020).

Palaeobotanical data, especially leaf and fruit prints of Buxus and Ficus, suggest warmer conditions at the time of La Celle tufa deposition (Limondin-Lozouet et al., 2006; Jolly-Saad et al., 2007). Furthermore, the occurrences of Macaca sylvanus and Hippopotamus contemporaneous with the climatic optimum (Limondin-Lozouet et al., 2006, 2010) indicate very temperate and wet conditions, respectively. All these palaeoenvironmental data strengthen the observations based on stable isotope comparison.

There are few continental records providing climatic reconstructions back to MIS 11 in western Europe. The closest to La Celle are lacustrine records in the French Massif Central (Le Velay) and in the Vercors (La Côte; Fig. 1), whose pollen assemblages suggest similar climatic conditions during MIS 11 and the Holocene (de Beaulieu et al., 1994; Reille et al., 2000). However, quantitative reconstructions based on Coleoptera from La Côte indicate that the MIS 11 climatic optimum was particularly warm (Field et al., 2000), as observed at La Celle. In a comparison of several MIS 11 continental records, especially from Europe, most indicate higher humidity than during the Holocene, but in temperature reconstructions, either similar or warmer conditions are reported across locations (Rousseau, 2003).

\section{CONCLUSIONS}

In globally significant records (e.g., from marine and ice cores), MIS 5 and 11 are the strongest interglacials of the last $800 \mathrm{ka}$, marked by higher sea levels, reduced ice sheets, higher atmospheric $\mathrm{CO}_{2}$, and finally, higher temperatures (Lang and Wolff, 2011; Past 
Interglacials Working Group of PAGES, 2016). It is noteworthy that most Pleistocene tufa deposits known in western Europe and providing reliable palaeoenvironmental data are assigned to one of these two interglacials (Pentecost, 1995; Limondin-Lozouet and Preece, 2014). Most exceptions occur in Thuringia (Germany), where partly fault-controlled cooled geothermal springs (i.e., partly independent of climatic conditions) fed massive tufa deposits (or "travitufa," according to Capezzuoli et al. [2014]) also during MIS 7 and 9 (e.g. Ehrinsdorf [MIS 7] and a part of the Bilzingsleben deposit [MIS 9], which is however mainly assigned to MIS 11; Mania and Mania, 2008). Tufa deposits have been shown to require temperate and, especially, wet climatic conditions (Pentecost, 2005; Capezzuoli et al., 2014), although they can start growing very quickly after the onset of such conditions, as demonstrated for the last climatic cycle by many late-glacial/Early Holocene tufas (Pentecost, 1995; Dabkowski, 2020). Therefore, the most frequent occurrence of MIS 5e and 11 tufas suggests that, in Europe, these interglacials must have been stronger, in terms of temperature and/or moisture availability, than MIS 7 and 9.

As tufas provide favourable (calcareous) conditions for both the development and preservation of molluscan communities (Preece, 1991), mollusc shells are usually well represented in quantity and quality within fossil deposits. Several European tufas have thus provided detailed assemblages comparable to those from Caours and La Celle (Fig. 8). As noted earlier, MIS 11, 5, and 1 are the best documented Pleistocene interglacials for malacological records from tufa deposits. During Pleistocene interglacials, the total number of land snails and of forest species systematically exceeds those observed during the Holocene (Limondin-Lozouet and Preece, 2014). Additionally, the highest malacological diversity is always recorded at MIS 11 sites (Fig. 8). In the studied area, the MIS 11 malacological assemblages include up to 41 species of forest molluscs, $50 \%$ of which are non-indigenous (out of range or extinct). Among these, a quarter are species originating from southern Europe. The occurrence of some strictly Mediterranean species during the optimum phase is a specificity of MIS 11 malacofaunas (Limondin-Lozouet et al., 2020). Such variations in molluscan diversity are likely related to differences in climatic parameters and in particular to higher moisture availability during MIS 5e and especially MIS 11 compared with the Holocene, which is consistent with our conclusions based on palaeoclimatic data from Caours, La Celle, and SGV. Unfortunately, few or no isotopic data are yet available from other Pleistocene tufas in Europe to further support these observations.

Figure 8. Number of forest land snails recorded in tufa deposits from Germany, France, and southern England (for site location, see Fig. 1).

Tufa stable isotopes therefore seem appropriate for comparing climatic conditions prevailing during the Holocene and Pleistocene interglacials, especially MIS 5 and MIS 11. Data from La Celle, Caours, and SGV suggest that in the Paris Basin:

- most of MIS 11, and especially its optimum, was wetter and warmer than the Holocene and MIS 5e;

- although weaker than MIS 11, MIS 5e experienced wetter conditions than the Holocene, especially during the optimum, but no clear difference is observed in terms of temperature, except for the climatic optimum that might have been slightly warmer during MIS 5e.

New investigations on recent and Pleistocene tufa deposits from France, Germany, England, and elsewhere in Europe should lead to a more complete record of differences and similarities between interglacials and would allow discussion of differences in interglacial climatic patterns at the European scale.

\section{Acknowledgments}

We thank both reviewers for their useful comments on the article. This paper is a contribution to the ANR project NEANDROOTS.

\section{References}

\section{(A)}

Andrews, J.E., 2006. Palaeoclimatic records from stable isotopes in riverine tufas: synthesis and review. Earth-Science Reviews 75, 85-104.CrossRefGoogle Scholar

(A)

Andrews, J.E., Riding, R., Dennis, P.F., 1993. Stable isotopic compositions of Recent 
freshwater cyanobacterial carbonates from the British Isles: local and regional environmental controls. Sedimentology 40, 303-314.CrossRefGoogle Scholar

Andrews, J.E., Riding, R., Dennis, P.F., 1997. The stable isotope record of environmental and climatic signals in modern terrestrial microbial carbonates from Europe. Palaeogeography, Palaeoclimatology, Palaeoecology 129, 171-189.CrossRefGoogle Scholar

(1)

Antoine, P., Limondin Lozouet, N., Auguste, P., Locht, J.-L., Ghaleb, B., Reyss, J.-L., Escudé, E., et al. , 2006. Le tuf de Caours (Somme, France): mise en évidence d'une séquence eemienne et d'un site paléolithique associé. Quaternaire 17, 281-320.CrossRefGoogle Scholar

(1)

Antoine, P., Limondin Lozouet, N., Chaussé, C., Lautridou, J.-P., Pastre, J.-F., Auguste, P. Bahain, J.-J., Falguères, C., Galehb, B., 2007. Pleistocene fluvial terraces from northern France (Seine, Yonne, Somme): synthesis, and new results from interglacial deposits. Quaternary Science Reviews 26, 2701-2723.CrossRefGoogle Scholar

(1)

Bahain, J.-J., Falguères, C., Dolo, J.-M., Antoine, P., Auguste, P., Limondin-Lozouet, N., Locht, J.-L., Tuffreau, A., Tissoux, H., Farkh, S., 2010. ESR/U-series dating of teeth recovered from well-stratigraphically age-controlled sequences from northern France. Quaternary Geochronology 5, 371-375.CrossRefGoogle Scholar

(A)

Bowen, G.J., 2020. The Online Isotopes in Precipitation Calculator, Version 3.1. http://www.waterisotopes.org (accessed December 15, 2020).Google Scholar

(1)

Bowen, G.J., Revenaugh, J., 2003. Interpolating the isotopic composition of modern meteoric precipitation: isotopic composition of modern precipitation. Water Resources Research 39. https://doi.org/10.1029/2003WR002086.CrossRefGoogle Scholar

(1)

Capezzuoli, E., Gandin, A., Pedley, M., 2014. Decoding tufa and travertine (fresh water carbonates) in the sedimentary record: the state of the art. Sedimentology 61, 1-21.CrossRefGoogle Scholar

(A)

Cheddadi, R., Mamakowa, K., Guiot, J., de Beaulieu, J.-L., Reille, M., Andrieu, V., Granoszewski, W., Peyron, O., 1998. Was the climate of the Eemian stable? A quantitative climate reconstruction from seven European pollen records. Palaeogeography, Palaeoclimatology, Palaeoecology 143, 73-85.CrossRefGoogle Scholar

(A)

Dabkowski, J., 2014. High potential of calcareous tufas for integrative multidisciplinary studies and prospects for archaeology in Europe. Journal of Archaeological Science 52, 72-83. CrossRefGoogle Scholar

\section{(A)}

Dabkowski, J., 2020. The late-Holocene tufa decline in Europe: myth or reality? Quaternary Science Reviews 230, 106141.CrossRefGoogle Scholar

(1)

Dabkowski, J., Limondin-Lozouet, N., Andrews, J., Marca-Bell, A., Antoine, P., 2016. Climatic and environmental dynamic during the Eemian recorded in a northern France tufa (Caours, Somme basin). Comparison with regional records. Quaternaire 27, 249-261.CrossRefGoogle $\underline{\text { Scholar }}$

(1)

Dabkowski, J., Limondin-Lozouet, N., Antoine, P., Andrews, J., Marca-Bell, A., Robert, V., 2012 Climatic variations in MIS 11 recorded by stable isotopes and trace elements in a French tufa (La Celle, Seine Valley): climatic variations in MIS 11 in a French tufa. Journal of Quaternary Science 27, 790-799.CrossRefGoogle Scholar

(1)

Dabkowski, J., Limondin-Lozouet, N., Antoine, P., Marca-Bell, A., Andrews, J., 2011.

Enregistrement des variations climatiques au cours des interglaciaires d'après l'étude des isotopes stables de la calref de tufs calcaires pléistocènes du nord de la France: exemple des séquences de Caours (SIM 5e; Somme) et de La Celle-sur-Seine (SIM 11; Seine-etMarne). Quaternaire 22, 275-283.CrossRefGoogle Scholar (1)

Darling, W.G., 2004. Hydrological factors in the interpretation of stable isotopic proxy data present and past: a European perspective. Quaternary Science Reviews 23, 743-770.CrossRefGoogle Scholar

(1)

de Beaulieu, J.-L., Eicher, U., Monjuvent, G., 1994. Reconstruction of Middle Pleistocene 
palaeoenvironments based on pollen and stable isotope investigations at Val-de-Lans, Isère, France. Vegetation History and Archaeobotany 3, 127-142.CrossRefGoogle Scholar (A) de Beaulieu, J.L., 1992. The last climatic cycle at La Grande Pile (Vosges, France). A new pollen profile. Quaternary Science Reviews 11, 431-438.CrossRefGoogle Scholar (A)

Field, M.H., de Beaulieu, J.-L., Guiot, J., Ponel, P., 2000. Middle Pleistocene deposits at La Côte, Val-de-Lans, Isère department, France: plant macrofossil, palynological and fossil insect investigations. Palaeogeography, Palaeoclimatology, Palaeoecology 159, 53-83.CrossRefGoogle Scholar

(A)

Garnett, E.R., Andrews, J.E., Preece, R.C., Dennis, P.F., 2004. Climatic change recorded by stable isotopes and trace elements in a British Holocene tufa. Journal of Quaternary Science 19, 251-262.CrossRefGoogle Scholar

(1) Jolly-Saad, M.-C., Dupéron-Laudoueneix, M., Dupéron, J., 2007. Nouvelle étude des empreintes foliaires des tufs holsteiniens de La Celle-sous-Moret (Seine-et-Marne). Palaeontographica Abteilung B 276, 145-160.CrossRefGoogle Scholar (1) Kühl, N., Litt, T., Schölzel, C., Hense, A., 2007. Eemian and Early Weichselian temperature and precipitation variability in northern Germany. Quaternary Science Reviews 26, 3311-3317.CrossRefGoogle Scholar

(1)

Lang, N., Wolff, E.W., 2011. Interglacial and glacial variability from the last $800 \mathrm{ka}$ in marine, ice and terrestrial archives. Climate of the Past 7, 361-380.CrossRefGoogle Scholar (1)

Lautridou, J.-P., Auffret, J.-P., Baltzer, A., Clet, M., Lécolle, F., Lefebvre, D., Lericolais, G., et al. , 1999. Le fleuve Seine, le fleuve Manche. Bulletin de la Société Géologique de France 170 545-558.Google Scholar

(A)

Limondin-Lozouet, N., 2011. Successions malacologiques à la charnière

Glaciaire/Interglaciaire: du modèle Tardiglaciaire-Holocène aux transitions du Pleistocène. Quaternaire 22, 211-220.CrossRefGoogle Scholar

(1)

Limondin-Lozouet, N., Antoine, P., Auguste, P., Bahain, J.-J., Carbonel, P., Chaussé, C., et al. 2006. Le tuf calcaire de La Celle-sur-Seine (Seine-et-Marne): nouvelles données sur un site clé du stade 11 dans le nord de la France. Quaternaire 17, 5-29.CrossRefGoogle Scholar (A)

Limondin-Lozouet, N., Dabkowski, J., Antoine, P., 2020. Palaeoenvironmental dynamics of the MIS 11 interglacial in north-western Europe based on the malacological succession from La Celle (Seine Valley, France): relationship with glacial refugia and palaeobiodiversity. Palaeogeography, Palaeoclimatology, Palaeoecology 560, 110044.CrossRefGoogle Scholar

(A)

Limondin-Lozouet, N., Gauthier, A., Preece, R.C., 2005. Enregistrement des biocènoses de la première moitié de I'Holocène en contexte tufacé à Saint-Germain-le-Vasson (Calvados)

Quaternaire 16, 255-271.CrossRefGoogle Scholar

(1)

Limondin-Lozouet, N., Nicoud, E., Antoine, P., Auguste, P., Bahain, J.-J., Dabkowski, J.,

Dupéron, J., et al. , 2010. Oldest evidence of Acheulean occupation in the Upper Seine valley (France) from an MIS 11 tufa at La Celle. Quaternary International 223-224,

299-311.CrossRefGoogle Scholar

(1)

Limondin-Lozouet, N., Preece, R.C., 2004. Molluscan successions from the Holocene tufa of St Germain-le-Vasson, Normandy (France) and their biogeographical significance. Journal of Quaternary Science 19, 55-71.CrossRefGoogle Scholar

(A)

Limondin-Lozouet, N., Preece, R.C., 2014. Quaternary perspectives on the diversity of land snail assemblages from northwestern Europe. Journal of Molluscan Studies 80,

224-237.CrossRefGoogle Scholar

(1)

Locht, J.L., Antoine, P., Auguste, P., Limondin-Lozouet, N., 2009. Caours "Les Prés," Rapport triennal de fouille programmée. SRA Picardie, Amiens.Google Scholar

(A)

Locht, J.L., Dabkowski, J., Antoine, P., Auguste, P., Sévêque, N., Moreau, G., Vialet, A., 
Bertrand, B., 2017. Caours, Rapport triennal de fouille programmée 2015-2017. SRA Picardie, Amiens. Google Scholar

(A)

Mania, D., Mania, U., 2008. La stratigraphie et le Paléolithique du complexe saalien dans la région de la Saale et de l'Elbe. L'Anthropologie 112, 15-47.CrossRefGoogle Scholar

(A)

Past Interglacials Working Group of PAGES, 2016. Interglacials of the last 800,000 years. Review of Geophysics 54, 162-219.CrossRefGoogle Scholar

(1)

Pentecost, A., 1995. The quaternary travertine deposits of Europe and Asia Minor

Quaternary Science Reviews 14, 1005-1028.CrossRefGoogle Scholar

(1)

Pentecost, A., 2005. Travertine. Springer-Verlag, Berlin.Google Scholar

(1)

Pomerol, C., 1974. Le bassin de Paris. In: Debelmas, J. (ed), Géologie de La France. Doin,

Paris. pp. 230-258.Google Scholar

(1)

Ponel, P., 1995. Rissian, Eemian and Würmian Coleoptera assemblages from La Grande Pile (Vosges, France). Palaeogeography, Palaeoclimatology, Palaeoecology 114,

1-41.CrossRefGoogle Scholar

(1)

Ponel, P., Orgeas, J., Samways, M.J., Andrieu-Ponel, V., de Beaulieu, J.-L., Reille, M., Roche, P., Tatoni, T., 2003. 110000 years of Quaternary beetle diversity change. Biodiversity \& Conservation 12, 2077-2089.CrossRefGoogle Scholar

(1)

Preece, R.C., 1991. Mapping snails in time: the prospect of elucidating the historical biogeography of the European malacofauna. In: Proceedings of the Xth International Malacological Congress, Tubingen, pp. 447-479.Google Scholar

(1)

Reille, M., de Beaulieu, J.L., Svobodova, H., Andrieu-Ponel, V., Goeury, C., 2000. Pollen analytical biostratigraphy of the last five climatic cycles from a long continental sequence from the Velay region (Massif Central, France). Journal of Quaternary Science 15, 665-685.3.0.CO;2-G>CrossRefGoogle Scholar

(1)

Rodet, J., 2007. Karst de la craie et aquifère de Normandie. European Journal of Water Quality 38, 11-21.CrossRefGoogle Scholar

(A)

Rousseau, D.-D., 2003. The continental record of stage 11: a review. In: Droxler, A.W., Poore, R.Z., Burckle, L.H. (Eds.), Earth's Climate and Orbital Eccentricity: The Marine Isotope Stage 11 Question. Geophysical Monograph Series 137. American Geophysical Union, Washington, DC, pp. 213-222.CrossRefGoogle Scholar

(1)

Rousseau, D.-D., Hatté, C., Duzer, D., Schevin, P., Kukla, G., Guiot, J., 2007. 15. Estimates of temperature and precipitation variations during the Eemian interglacial: new data from the grande pile record (GP XXI). In: Sirocko, F., Claussen, M., Sánchez Goñi, M.F., Litt, T. (eds), The Climate of Past Interglacials. Elsevier, Amsterdam, pp. 231-338.CrossRefGoogle Scholar (1)

Rousseau, D.-D., Puisségur, J.-J., Lécolle, F., 1992. West-European terrestrial molluscs assemblages of isotopic stage 11 (Middle Pleistocene): climatic implications. Palaeogeography, Palaeoclimatology, Palaeoecology 92, 15-29.CrossRefGoogle Scholar (1)

Rousseau, D.D., Hatté, Ch., Guiot, J., Duzer, D., Schevin, P., Kukla, G., 2006. Reconstruction of the Grande Pile Eemian using inverse modeling of biomes and $\delta^{13} \mathrm{C}$. Quaternary Science Reviews 25, 2806-2819.CrossRefGoogle Scholar

(A)

Sánchez Goñi, M.F., Bakker, P., Desprat, S., Carlson, A.E., Van Meerbeeck, C.J., Peyron, O., Naughton, F., et al. , 2012. European climate optimum and enhanced Greenland melt during the Last Interglacial. Geology 40, 627-630.CrossRefGoogle Scholar

(A)

Sánchez Goñi, M.F., Loutre, M.F., Crucifix, M., Peyron, O., Santos, L., Duprat, J., Malaizé, B., Turon, J.-L., Peypouquet, J.-P., 2005. Increasing vegetation and climate gradient in Western Europe over the Last Glacial Inception (122-110 ka): data-model comparison. Earth and Planetary Science Letters 231, 111-130.CrossRefGoogle Scholar 
Shakun, J.D., Lea, D.W., Lisiecki, L.E., Raymo, M.E., 2015. An 800-kyr record of global surface ocean $\delta{ }^{18} \mathrm{O}$ and implications for ice volume-temperature coupling. Earth and Planetary Science Letters 426, 58-68.CrossRefGoogle Scholar

(A)

Sier, M.J., Parés, J.M., Antoine, P., Locht, J.-L., Dekkers, M.J., Limondin-Lozouet, N.,

Roebroeks, W., 2015. Evidence for the Blake Event recorded at the Eemian archaeological site of Caours, France. Quaternary International 357, 149-157.CrossRefGoogle Scholar

(1)

Teadadsis, P.C., Raynaud, D., McManus, J.F., Berger, A., Brovkin, V., Kiefer, T., 2009

Interglacial diversity. Nature Geoscience 2, 751-755.CrossRefGoogle Scholar Related content

Wioiptard, G., 1978. Grande Pile peat bog: a continuous pollen record for the last 140,000

yeingstable Istegne DataResearch 9, 1-21.CrossRefGoogle Scholar
Hugh Rollinson and Victoria Pease

Using Geochemical Data

Published online: 15 April 202

Article

Last Interglacial Climates

George J. Kukla, Michael L. Bender, Jacques-Louis de Beaulieu, Gerard Bond, Wallace S. Broecker, Piet Cleveringa, Joyce E.

Gavin, Timothy D. Herbert, John Imbrie, Jean Jouzel, Lloyd D. Keigwin, Karen-Luise Knudsen, Jerry F. McManus, Josef Merkt, Daniel R. Muhs, Helmut Müller, Richard Z. Poore, Stephen C. Porter, Guy Seret, Nicholas J. Shackleton, Charles Turner, Polychronis C.

Tzedakis and Isaac J. Winograd

Quaternary Research

Published online: 20 January 2017

Article

A multiproxy record of sedimentation, pedogenesis, and environmental history in the north of West Siberia during the late

Pleistocene based on the Belaya Gora section

Vladimir Sheinkman, Sergey Sedov, Lyudmila S. Shumilovskikh, Elena Bezrukova, Dmitriy Dobrynin, Svetlana Timireva, Alexey

Rusakov and Fedor Maksimov

Quaternary Research

Published online: 9 October 2020

Article

Life histories and niche dynamics in late Quaternary proboscideans from midwestern North America

Chris Widga, Greg Hodgins, Kayla Kolis, Stacey Lengyel, Jeff Saunders, J. Douglas Walker and Alan D. Wanamake

Quaternary Research

Published online: 23 October 2020

Article

Paleoclimatic reconstruction in the Tatra Mountains of the western Carpathians during MIS 9-7 inferred from a multiproxy speleothem record

Marcin Błaszczyk, Helena Hercman, Jacek Pawlak and Jacek Szczygie

Quaternary Research

Published online: 11 September 2020

Article

Reconstruction of sea-surface temperatures in the Canary Islands during Marine Isotope Stage

Thibault Clauzel, Chloé Maréchal, François Fourel, Abel Barral, Romain Amiot, Juan-Francisco Betancort, Alejandro Lomoschitz, Joaquín

Meco and Christophe Lécuyer

Quaternary Research

Published online: 20 November 2019

Article

Hydrologic and climatic implications of stable isotope and minor element analyses of authigenic calcite silts and gastropod shells from a mid-Pleistocene pluvial lake, Western Desert, Egypt

Quaternary Research

Published online: 20 January 2017

Article

Effective precipitation in southern Spain ( 266 To $46 \mathrm{Ka}$ ) based on a speleothem stable carbon isotope record

Edward J. Hodge, David A. Richards, Peter L. Smart, Bartolomé Andreo, Dirk L. Hoffmann, Dave P. Mattey and Antonio González-

Ramón

Quaternary Research

Published online: 20 January 2017

Article

Seasonal paleoecological records from antler collagen $\delta^{13} \mathrm{C}$ and $\delta^{15} \mathrm{~N}$

Rachel Schwartz-Narbonne, Tessa Plint, Elizabeth Hall, Grant Zazula and Fred J. Longstaffe

Paleobiology

Published online: 5 March 2021

Article

Global glacier dynamics during $\mathbf{1 0 0}$ ka Pleistocene glacial cycles

Philip D. Hughes and Philip L. Gibbard

Quaternary Research

Published online: 4 June 2018 
